\title{
Designing the CORONIS trial. Why a non-regular fractional factorial design?
}

\author{
Pollyanna Hardy*, Ed Juszczak, Barbara Farrell \\ From 2nd Clinical Trials Methodology Conference: Methodology Matters \\ Edinburgh, UK. 18-19 November 2013
}

\section{Introduction}

Caesarean section is one of the most commonly performed operations worldwide. A variety of surgical techniques for all elements of the operation are used. Many of them have not been rigorously evaluated in randomised controlled trials. The CORONIS Trial set out to simultaneously examine five elements of the caesarean section operation in seven low- to middle-income countries, using a novel adaptation of the factorial design.

\section{Design}

During the planning stages of CORONIS, five pairs of caesarean section techniques were agreed upon using a consensus process, for evaluation in a factorial design. It subsequently became apparent that, for pragmatic reasons, not all five pairs could be randomly allocated in all participating countries. Therefore, each participating site was assigned 3 of the 5 intervention pairs. In addition it was agreed that examining interactions was not important. This led to the adoption of a non-regular fractional factorial design, the first known use of its kind in a clinical trial setting. This presentation will explain how pragmatic considerations influenced the design of the CORONIS Trial and their implications on the sample size, randomisation, central monitoring, conduct and analysis.

\section{Conclusions and recommendations}

Our experience of using a complex trial design to deliver robust and reliable results was successful, but required a team of innovative researchers and clinicians. We would recommend undertaking such a design only with extreme caution.

\footnotetext{
National Perinatal Epidemiology Unit, University of Oxford, Oxford, UK, on
} behalf on the CORONIS Trial Collaborative Group, Oxford, UK
Published: 29 November 2013

\section{References}

1. CORONIS Trial Collaborative Group: The CORONIS Trial. BMC Pregnancy and Childbirth 2007, 7:24.

2. Mee RW: A Comprehensive Guide to Factorial Two-Level Experimentation. Springer; 2009.

doi:10.1186/1745-6215-14-S1-057

Cite this article as: Hardy et al:: Designing the CORONIS trial. Why a non-regular fractional factorial design? Trials 2013 14(Suppl 1):O57.
Submit your next manuscript to BioMed Central and take full advantage of:

- Convenient online submission

- Thorough peer review

- No space constraints or color figure charges

- Immediate publication on acceptance

- Inclusion in PubMed, CAS, Scopus and Google Scholar

- Research which is freely available for redistribution
() Biomed Central 